\title{
Tudományos teljesítmény mérése a magyar felsőoktatás gazdasági képzéseiben
}

\begin{abstract}
A nemzetközi egyetemi rangsorokban a tudományos teljesítmény mérése kap nagy hangsúlyt, míg a magyar egyetemi rangsorolási gyakorlat kisebb mértékben jeleníti meg ezt, és a nemzetközi irodalomtól eltérően nem a publikációs teljesítmény alapján számolja. Tanulmányunk a Magyar Tudományos Müvek Tárhelyén (MTMT) alapuló egyedi adatok segítségével arra ad több lehetséges példát, hogyan lehetne egy fontos szempontot a tudományos publikációk alapján beépíteni a magyar egyetemi rangsorokba. Azt is megmutatjuk, hogy számos megközelítés alkalmazható, de ezek nagyon hasonló következtetésre jutnak. Tehát a tudományos publikáción alapuló új szempont robusztus eredményt ad.*

Journal of Economic Literature (JEL) kód: I23.
\end{abstract}

A tanulmány célja annak vizsgálata, hogy a jelenlegi hazai felsőoktatási rangsorok milyen mértékben tudják megfogni az oktatási minőség tudományos publikációs teljesítmény aspektusát. Szeretnénk hozzájárulni a bibliográfiai mutatók magyar gyakorlatba való beépüléséhez, valamint felhívni a figyelmet - a nemzetközi trendekkel összhangban - a felsőoktatás kutatási eredményeinek fontosságára.

A felsőoktatási rangsorok kialakítása és az intézmények értékelése az 1990-es évektől kezdődően sürün kutatott terület. Relevanciáját az állami döntéshozók számára a felsőoktatási reformok adták. Például Nagy-Britannia kormányzata a felsőoktatás hatékonyságának növelése céljából 1985-től javasolta az egyetemek számára különböző teljesítménymutatók létrehozását (Pollitt [1990]). A kínai oktatási minisztérium pedig 1995-ben indította a nagyszabású Project 211 kezdeményezést, amelynek célja kijelölt kínai egyetemek világszintű kutatóegyetemekké válásának támogatása a társadalmi és gazdasági fejlődés előmozdítása érdekében. A felsőoktatási intézmények

\footnotetext{
* Az elemzés az Emberi Erőforrások Minisztériuma Új Nemzeti Kiválóság Program (ÚNKP-18-3I-BCE-111) pályázatának támogatásával készült.
}

Csóka Imola PhD-hallgató, BCE Makroökonómia Tanszék.

Neszveda Gábor egyetemi tanársegéd, BCE MNB Tanszék.

Sebestyén Géza egyetemi docens, BCE MNB Tanszék.

A kézirat első változata 2019. december 7-én érkezett szerkesztőségünkbe.

DOI: http://dx.doi.org/10.18414/KSZ.2019.7-8.751 
számára a téma kutatását a versenyképesség javítása, marketingcélok és a finanszírozási források elosztásának optimalizálása motiválta. A nemzeti rangsorok is ebben az időszakban jelentek meg, kezdve 1987-ben az US News rangsorával. Magyarországon 2001-ben indult a UnivPress rangsor (Fábri [2016]), a 2000-es évektől pedig egyre több globális rangsor elérhető, szintén jelezve a téma fontosságát.

Elöször az alapján mutatjuk be a nemzetközi és magyar rangsorokat, hogy melyik mit mér, mi a célja, filozófiája, valamint hogyan jeleníti meg a publikációkat és a tanár/diák arányt. Ezt követően áttekintjük a nemzetközi rangsorolási szakirodalmat - a bibliográfiai mutatókra és a tanár/diák arányra koncentrálva -, majd a felsőoktatási rangsorolást érő kritikákat. Ezek után az MTMT publikációs adatbázisának felhasználásával több lehetséges mérőszámot képzünk, amelyek alapján rangsoroljuk a magyar felsőoktatás gazdasági képzést nyújtó karait. Vizsgáljuk az összes publikációk számát, megkülönböztetjük a magyar és idegen nyelvűeket, valamint a különbözö besorolásúakat eltérő súlyokkal szerepeltetjük, továbbá ezek egy oktatóra vagy diákra jutó számát is megnézzük. A felsorolt bibliográfiai mutatók a tudományos teljesítmény valamelyest eltérő oldalait ragadják meg, mégis korrelációs elemzéssel rámutatunk, hogy a különböző indikátorok között erős kapcsolat figyelhető meg, a sorrend hasonlóan alakul mindegyik esetben, a kapott eredmények tehát robusztusnak tekinthetők. A tanár/diák arány és az egy hallgatóra jutó minősített oktatók száma alapján kialakult sorrend viszont az eddigiektől jelentősen eltér, tehát a tudományos publikációk alapján képzett mutatók érdemben különböző információt tartalmaznak.

\section{Nemzetközi és magyar rangsorok}

A következőkben bemutatjuk, hogy az oktatói kiválóságot milyen tulajdonsággal jellemzik a magyar, illetve a nemzetközi globális rangsorok. A globális rangsorok többségéről elmondható, hogy főként a tudományos publikációs és idézettségi adatokból táplálkoznak, viszont a kutatási teljesítmény mérésére eltérő módszertant használnak. Az Academic Ranking of World Universities (ARWU) rangsora kizárólag a nemzetközileg elismert kutatási teljesítményt veszi figyelembe: a rangsorba való bekerülés feltétele, hogy az egyetem rendelkezzen magas idézettségü kutatóval vagy jelentős mennyiségü indexált cikkel, ${ }^{1}$ ez utóbbi 25 százalékos súllyal szerepel ( $A R W U$ [2018]). A Leiden rangsora az egyetem hatását és tudományos együttmüködéseit értékeli olyan dimenziók szerint, mint például az idézettség alapján felső 1,10 vagy 50 százalékba tartozó publikációk száma és aránya, a publikációk idézettségének teljes és átlagos száma, más országgal vagy ipari szervezettel társszerzős cikkek száma és aránya (Leiden Ranking [2018]). A Scimago a kutatáson és az internetes láthatóságon kívül az innovációt is figyelembe veszi, amelynek mérésére a szabadalmakban való idézettséget alkalmazza, továbbá nemcsak egyetemeket, hanem más akadémiai és

${ }^{1}$ A következő indexálást veszi figyelembe az ARWU (más néven Shanghai Ranking): Science Citation Index-Expanded (SCIE) és Social Science Citation Index (SSCI). Emellett figyelembe veszi, hogy rendelkeznek-e Nobel-díjjal kitüntetett alkalmazottal vagy végzett hallgatóval. 
kutatási intézményeket is rangsorol. A Scopus adatbázisában nyilvántartott publikációk száma a végső pontszám 8 százalékát alkotja (Scimago [2018]).

A US News, a QS World University Rankings és a Times Higher Education (THE) rangsorai az előbbieknél tágabb körüek, hiszen az egyetem nemzetköziségét, oktatási teljesítményét (QS és THE) és reputációs megítélését is értékelik. Közös jellemvonásuk, hogy mindhárom mutatóban ez utóbbi szempont a legmeghatározóbb. A US News pontszámában összesen 15 százalék súllyal szerepelnek a tudományos publikációk (10 százalék), a könyvek (2,5 százalék) és a konferenciakötetek (2,5 százalék), a THE rangsorában pedig 6 százalékot jelent az egy kutatóra jutó publikációk száma. A publikációk számításához a US News a Web of Science ${ }^{2}$ adatbázisát használja, a THE pedig a Scopust. A tanár/diák arány a vizsgált globális rangsorok közül csupán a THE és a QS indikátorai közt szerepel, rendre 4,5, valamint 20 százalékos súllyal. Az összes egy före jutó mutatót teljes munkaidővel egyenértékü (full time equivalent, FTE) módon számítják, a THE esetében egyedi módszertannal, a QS pedig a teljes munkaidős foglalkoztatottakat és diákokat 1, a részmunkaidősöket pedig 1/3 súllyal (Morse és szerzőtársai [2018], QS [2018]).

Az U-Multirank rangsorának megközelítése jelentősen eltér az eddig bemutatottaktól - hiszen nem célja egyetlen végső rangsor (league table) létrehozása meghatározott súlyokkal -, mert többdimenziós, átfogó és felhasználóbarát is egyben. Rugalmas online felületének segítségével személyre szabott rangsorlistákat hozhatunk létre a több mint száz elérhető indikátor alapján, amelyek között szerepel mind a tanár/diák arány, mind az egy diákra, valamint egy tanárra jutó publikációk száma is (U-Multirank [2018]).

Emellett léteznek még más rangsor-megközelítések, mint a Webometrics, de ezeknek kisebb a jelentőségük. A Webometrics rangsorának eredeti célja az internetes jelenlét elösegítése volt, így föleg az internetes tartalmak és linkek alapján rangsorol abból a megfontolásból, hogy a 21. században az internet kulcsfontosságú az egyetemek küldetésének jövője szempontjából. Ez a legtöbb intézményt lefedö felsőoktatási rangsor, húszezer feletti felsőoktatási intézményt értékel, míg a legtöbb nemzetközi rangsor az erős bekerülési kritériumok miatt csupán néhány százat (Webometrics [2018]).

Ami a magyar rangsorokat illeti, egyedül a UnivPress rendelkezik összehasonlítható adatokkal, ezenkívül a Heti Válasz jelentetett meg rendszeresen felsőoktatási rangsort, viszont módszertana többször is megváltozott, valamint inkább üzleti, mintsem akadémiai jellegü. Mindkét rangsor föleg a felvételizettek mutatóit - például pontszám, nyelvvizsga - veszi figyelembe, a UnivPress ezenfelül az oktatók minősítéseit (habilitáció, MTA-cím), valamint az OTDK-helyezéseket, PhD-hallgatókat és PhD-fokozatot szerzetteket, a Heti Válasz pedig a végzettek bruttó jövedelmét és a felsőfokú végzettséget igénylő munkában foglalkoztatottak arányát (Fábri [2016]). A tanár/diák arány, pontosabban a minősített oktatóra jutó nappalis hallgatók száma 13 százalék a UnivPress rangsorban, míg a Heti Válaszból 2012 után kikerült ez a fajta indikátor. A használt indikátorok közül több esetében is megkérdőjelezhető, hogy valóban alkalmas-e az egyetem teljesítményének mérésére, a legkomolyabb probléma mégis abból adódik, hogy egyik magyar rangsor

\footnotetext{
${ }^{2}$ Régebbi nevén Thomson Reuters.
} 
sem alkalmaz bibliometriai mutatókat. Ezzel élesen elkülönül a nemzetközi trendektől, és az egyetemi minőségbiztosítás itthon és külföldön is elfogadott és alkalmazott irányelveitől. Ezen szempontok mellett felmerült a magyar szakirodalomban is több lehetséges megközelítés, amelyek leginkább a diákok jelentkezési sorrendjei alapján állítanak fel rangsorokat (Csató [2013], [2016], Telcs és szerzőtársai [2013]).

\section{Az oktatói kiválóság mérése - tanár/diák arány és publikációk}

A nemzetközi és magyar rangsorok összefoglalását tartalmazza az 1. táblázat a két fő indikátor alapján, kiemelve az egyes mutatók tartalmát.

\section{1. táblázat}

Nemzetközi és magyar rangsorok összefoglalója

\begin{tabular}{|c|c|c|c|}
\hline & Tanár/diák arány & Publikáció & Tartalom \\
\hline THE & tanár/diák arány & publikáció/kutató & $\begin{array}{l}\text { reputáció, oktatás, kutatás, } \\
\text { idézettség, nemzetköziség }\end{array}$ \\
\hline QS & tanár/diák arány & - & $\begin{array}{l}\text { reputáció, oktatás, idézettség, } \\
\text { nemzetköziség }\end{array}$ \\
\hline US News & - & publikációk száma & $\begin{array}{l}\text { reputáció, teljes és top publikációk, } \\
\text { idézettség, nemzetköziség }\end{array}$ \\
\hline ARWU & - & top publikációk & $\begin{array}{l}\text { csak magas minőségü kutatás } \\
\text { (Nobel-díj, idézettség, top folyóirat) }\end{array}$ \\
\hline Webometrics & - & a Google scholarban & internetes jelenlét és hatás \\
\hline Leiden & - & top publikációk & $\begin{array}{l}\text { hatás (idézettség, publikáció) és } \\
\text { tudományos együttműködések }\end{array}$ \\
\hline Scimago & - & publikációk száma & $\begin{array}{l}\text { kutatás, szabadalmak, internetes } \\
\text { láthatóság }\end{array}$ \\
\hline U-Multirank & diák/tanár arány & $\begin{array}{l}\text { publikáció/diák arány, } \\
\text { publikáció/tanár arány }\end{array}$ & $\begin{array}{l}\text { nincs egy összetett rangsor, hanem } \\
\text { egyedi indikátorok }\end{array}$ \\
\hline UnivPress & $\begin{array}{l}\text { nappalis hallgató/ } \\
\text { minősített oktató } \\
\text { arány }\end{array}$ & - & $\begin{array}{l}\text { fóként a felvételizők mutatói, } \\
\text { plusz PhD, OKTV, tanárok } \\
\text { fokozata, diák/tanár arány }\end{array}$ \\
\hline Heti Válasz & $-^{*}$ & - & $\begin{array}{l}\text { csak a felvettek minősége és } \\
\text { későbbi foglalkoztatási adatai }\end{array}$ \\
\hline
\end{tabular}

* 2012-ig része volt a Heti Válasz rangsorának a diák/tanár arány.

Forrás: saját szerkesztés.

A bemutatott rangsorok közül csupán kevés használja a tanár/diák arányt (THE, QS, U-Multirank, UnivPress, Heti Válasz régebben), a legtöbb külföldi rangsornál inkább a publikációk száma a hangsúlyos (THE, ARWU, Webometrics, Scimago, US News, U-Multirank), amelyet szinte mindig három-öt éves időtartamra vetítve adnak össze, kiküszöbölve az ingadozásokat, valamint számolva a publikációs és 
tudásteremtő folyamat hosszával, akárcsak a nemzetközi szakirodalomban (lásd például Johnes [1987], Chatzimichael és szerzötársai [2017]). A nemzetközi rangsorok az összehasonlíthatóság kedvéért általában a Scopus vagy pedig a Web of Science adatbázisának segítségével hozzák létre a bibliográfiai mutatókat, viszont nemzeti rangsorok esetében a hazai, angoltól különböző nyelvű publikációk beszámítása is értékes információval szolgálhat.

A publikációk száma mellett gyakori mutató az idézettség (THE, QS, ARWU, Webometrics, Leiden, Scimago, US News), hiszen ez megragadhatja a kutatás hatását és a létrejött tudástranszfert. Sok helyütt használják még a rangsor elején lévő újságokban publikált cikkek számát és a legtöbbet idézett publikációk számát, a nemzetköziséget, a reputációt, valamint az internetalapú mutatókat.

Az oktatói kiválóság mérése és így a tanár/diák arány, illetve a tudományos teljesítmény szerepe a nemzetközi irodalomban is megjelenik. A tanár/diák arány mint az oktatás minőségét mutató rangsorképzö ismérv (Johnes [1987], Toutkoushian és szerzötársai [2003]). Bennett [2001] azzal a kritikával illet több mutatót is - köztük a tanár/diák arányt -, hogy legjobb esetben is csak pillanatképet nyújt arról, melyek lehetnek a minőség összetevői, és ez olyan, mint egy tortát az összetevői alapján megítélni kóstolás helyett, hiszen az oktatás minősége e források hatékony felhasználásán múlik. Török [2008] is amellett érvel, hogy nem lehet értelmes rangsort állítani csupán a bemeneti mutatók alapján, hiszen a kimeneti teljesítményt ezenkívül a hatékonyság is nagyban meghatározza. Az oktatás minőségét jellemző egyéb mutatók terén a nemzeti és nemzetközi rangsorok gyakran használják a következő mutatókat: diákok véleményei, végzettek megtartása, oktatók díjai, elismerései, rangja, jövedelmi tényezők (Pollitt [1990]).

A nemzetközi irodalomban többször is megjelenik, hogy az oktatás és a kutatás egymást kiegészítő vagy éppen helyettesítő tevékenységek is lehetnek, így óvatosnak kell lenni, hiszen elöfordulhat, hogy egyik a másik kárára változtatható (Johnes [1987], Brooks [2005], Toutkoushian és szerzőtársai [2003], Chatzimichael és szerzötársai [2017], Johnes [2018]). Az egyetem három misszója (oktatás, kutatás-fejlesztés, szolgáltatás) esetén nem biztos, hogy az egyikben való javulás a másikban is magasabb minőséget eredményez (Safón [2013]). Különbség továbbá, hogy a tanár/diák arány inkább input- (Cakir és szerzőtársai [2015], Bennett [2001]), a publikációk száma pedig outputmutató, valamint a tanár/diák arány inkább a nemzeti, míg a publikációk száma inkább a nemzetközi rangsorok jellemzője (Cakir és szerzőtársai [2015], Johnes [2018]), ahogy azt az 1. táblázatban is láthatjuk. Török [2008] ilyen szempontból is élesen kritizálja a magyar rangsorokat, mivel egyáltalán nem veszik figyelembe a $\mathrm{K}+\mathrm{F}$-teljesítmény mutatóit, amelyek - különösen PhD-szinten - fontos kimeneti, minőségi mutatók (Toutkoushian és szerzőtársai [2003]).

Eleinte a kutatási teljesítményt a kiadási mutatókkal fejezték ki az adatok hozzáférhetősége miatt (Toutkoushian és szerzőtársai [2003]), majd a 2000-es évektől hangsúlyossá váltak a bibliográfiai mutatók: publikációk, idézettségen alapuló indikátorok. A kutatási teljesítmény témája sűrün kutatott terület, a régebbi cikkek a publikációk mérésének fontosságára hívják fel a figyelmet, az újabbak pedig inkább kritizálják, finomítják a mutatót - például a publikációk mellett az idézettség figyelembevételével vagy az újságok különböző súlyozásával, hogy a mennyiség mellett a minőség is szempontként 
szerepeljen (lásd Chatzimichael és szerzötársai [2017]). Javasolják, hogy a mennyiségi mutatók helyett a minőségi mutatókra érdemes koncentrálni, valamint kiemelik, hogy e két fogalom nem felcserélhetö (Pollitt [1990], Johnes [1987], Brooks [2005], Tachibana [2017], Bennett [2001], Chatzimichael és szerzötársai [2017]).

A bibliográfiai mutatók tekintetében mind a rangsorok, mind a szakirodalom két különböző indikátort is vizsgál. Előfordul, hogy a publikációk teljes számát veszik figyelembe, máshol pedig a teljes munkaidővel egyenértékű (FTE) tanárokra jutó arányt, hogy kiszürjék a méret okozta torzítást. A szakirodalom inkább ez utóbbi mellett érvel (Bennett [2001], Toutkoushian és szerzőtársai [2003], Chatzimichael és szerzötársai [2017], Safón [2013]), viszont Brooks [2005] kritikával illeti az egy före jutó mutatót, mivel a hatékonyságot részesíti előnyben a minőséggel szemben. A nevező, azaz a tanárok számának megállapításakor probléma léphet fel az egyetemek közt mozgó oktatók és a több helyen tanítók (interdisciplinary activity, például statisztika, matematika) beszámításánál (Johnes [1987], Brooks [2005], Moed [2017]), hiszen ezekben az esetekben egyegy oktató több különböző tanszék munkájához is hozzájárul.

Kritika éri a nemzetközi rangsorokat olyan szempontból, hogy egydimenziósak (Claassen [2015], Moed [2017]), és számos torzítást tartalmaznak, amely általában az angol nyelvterületü, nagy, kutatásközpontú természettudományi egyetemeknek kedvez (Safón [2013], Witte-Hudrlikova [2013], Marginson [2014], Fábri [2016]), ezáltal értékítéletet mondva az egyetem különböző funkciói között (oktatás, kutatás-fejlesztés, szolgáltatás) előnyben részesíti a kutatást az oktatással szemben. Több szerző is hangsúlyozza, hogy nem létezik egyetlen, teljeskörüen elfogadott indikátor vagy indikátorcsoport sem, amely tökéletesen mérné az egyetem (oktató) kiválóságát (Bennett [2001], Moed [2017], Török [2008], Johnes [2018], Tachibana [2017]), hiszen az egyetemek feladata nagyon sokrétü (Witte-Hudrlikova [2013]). Ennek ellenére a különböző rangsorok nagy hatással vannak az intézmények viselkedésére (Johnes [1987], Johnes [2018], Hazelkorn [2007]), így a megfelelő módszertan kialakítása rendkívül fontos. Mivel nem létezik egységes, kellően megalapozott módszertan, és a súlyozás önkényes, így vannak, akik megkérdőjelezik a kompozit indexek használatát (Marginson [2014]), valamint több cikk született a súlyozás problémájának korrekciójára (Witte-Hudrlikova [2013], Johnes [2018]).

Tanulmányunk legalább három módon is hozzájárul a szakirodalomhoz. Először, több - lehetséges tudományos publikációkon alapuló - mutatószámot is megvizsgál, amelyekkel kiegészíthetők a magyar felsőoktatási rangsorok szempontjai. Másodszor, bemutatja, hogy ezek a méröszámok nagyon hasonló következtetésre jutnak, így az eredmény robusztus és megbízható. Végül, megmutatjuk, hogy ezek a mutatószámok érdemben különböző információt tartalmaznak az eddig használt tanár/diák arányhoz képest.

\section{Tudományos teljesítményt mérő mutatószámok}

A magyar gazdasági felsőoktatási képzések publikációs teljesítményét a Magyar Tudományos Művek Tárhelye (MTMT) adatbázisából számítottuk. Minden felsőoktatási kar oktatóinak vettük a publikációs teljesítményét az MTMT-ben 2017 végén elérhető adatok 
alapján. 2013-tól 2017-ig minden évre kiszámítottuk, hogy az adott kar hány külföldi és hazai $A, B$, $C$, és $D$ kategóriájú tudományos müvet publikált. Az MTMT a folyóiratbesorolást az MTA IX. Gazdaság- és Jogtudományok Osztálya Gazdaságtudományi Doktori Minősítő Bizottságának folyóiratlistája alapján készítette.

Az MTMT adatbázis a Magyar Tudományos Akadémia által közfeladatként müködtetett nemzeti tudományos bibliográfiai adatbázis, amelynek szabályozási keretét a Magyar Tudományos Akadémiáról szóló 1994. évi XL. törvény 2015. július 21-én hatályba lépett módosítása adja. Az MTMT célja egy sok célra hasznosítható nemzeti bibliográfiai adatbázis megteremtése volt. Az MTMT alapító intézményei a Magyar Tudományos Akadémia, a Magyar Felsőoktatási Akkreditációs Bizottság (MAB), a Magyar Rektori Konferencia, az Országos Tudományos Kutatási Alapprogramok (OTKA) és az Országos Doktori Tanács (ODT).

Az MTMT-nek számos előnye van a hazai publikációs teljesítmény mérése tekintetében. Országosan egységes rendszerben kezeli a tudományos munkát; az ODT, ${ }^{3}$ az $\mathrm{OTKA}^{4}{ }^{4} \mathrm{MAB}^{5}$ és az MTA ${ }^{6}$ is ezt használja, illetve támogatja; az oktatási intézmények is ezt veszik figyelembe habilitáció, belső pályázatok, doktori képzés esetén; az oktatók jellemzően ismerik; a karbantartása viszonylag egyszerü; számos intézmény az MTMT-t veszi alapul az oktatói teljesítmények értékelése során is. Ezen ösztönzők is elősegítik az MTMT adatbázis aktualitását, ahogyan az is, hogy számos intézmény megköveteli oktatóitól, hogy évente legalább egyszer frissítsék adataikat. További előnye ennek az adatbázisnak, hogy kategorizálja a tudományos teljesítményt (a számunkra releváns müveket az MTA IX. osztályának folyóiratlistája alapján).?

Az MTMT-ben tárolt adatok karbantartása a szerzők feladata. Mivel ennek elmulasztása nem jár effektív szankciókkal, így egyes oktatóknál természetesen elképzelhetők kisebb-nagyobb eltérések a valós tudományos teljesítmény és az MTMT-ben szereplő adatok között. Ezen lehetséges torzítás ellenére ${ }^{8}$ kijelenthetjük, hogy ez az az adatbázis, amelynek karbantartása a hazai oktatóknak leginkább érdekében áll, és szintén ez az az adatbázis, mely a magyar nyelvü teljesítményt is méri. Az alternatív nemzetközi adatbázisok ezzel szemben nem igazán mérik a magyar nyelvű publikációs teljesítményt, illetve sokkal torzítottabbak, hiszen az oktatóknak jellemzően nincsen motivációjuk ezen adatbázisok karbantartására.

A fentiek mellett azt is megvizsgáltuk, hogy az MTMT adatai alapján készült publikációs rangsor mennyire van összhangban egy elismert nemzetközi adatbázis, a RePEc (Research Papers in Economics) adataiból számított rangsorral. A RePEc egy 99 országot lefedő, elsősorban közgazdaságtani témájú publikációk (műhelytanulmányok, szakcikkek, könyvek és könyvfejezetek, szoftverkomponensek) bibliografikus adatbázisa, amely több mint 50 ezer szerzőtől tartalmaz müveket (http://repec.org).

\footnotetext{
${ }^{3}$ https://doktori.hu/index.php?menuid=194\&lang=EN\&th_ID=50.

${ }^{4} \mathrm{https} / / / \mathrm{nkfih} . g o v \cdot h u /$ palyazatok/elektronikus-rendszer/adatok-importalasa-mtmt\#.

${ }^{5}$ www.mab.hu/web/doc/beadvanyok/160708DIutmutH.docx.

${ }^{6} \mathrm{https}: / / \mathrm{mta} \cdot \mathrm{hu} / \mathrm{hatteranyagok} / \mathrm{jelentkezes-a-koztestuletbe-a-felveteli-eljaras-rendje-105540.}$

${ }^{7} \mathrm{https} / / / \mathrm{mta} . \mathrm{hu} /$ data/dokumentumok/doktori_tanacs/IX.\%20Osztaly/2019/IX.O_folyoiratlistak_ 2017-OKT_AJB_PTB_GMB_2018.xlsx.

${ }^{8}$ Az MTMT-vel kapcsolatos egyes kihívásokról lásd Csaba és szerzőtársai [2014].
} 
Az általunk használt adatbázis mellett szól az is, hogy az MTMT és a RePEc alapján készült egyetemi kari rangsorok rangkorrelációja nagyon magas, értéke számos esetben a 0,95 -ot is meghaladja.

A két rangsor összevetése azonban csak részben végezhető el. Egyrészt nem minden általunk vizsgált kar regisztrált a RePEc adatbázisába (a 25-ből 21). Másrészt vannak olyan elismert hazai tudományos mühelyek, amelyek elökelő helyen szerepeltek a RePEc listáján, azonban nem rendelkeztünk megfelelően összehasonlítható kari MTMT-adatokkal róluk. ${ }^{9}$ Idesorolható a CEU Közgazdaságtudományi és Üzleti Tanulmányok Tanszéke (mivel a CEU nem rendelkezik karokkal), illetve az MTA Közgazdaságtudományi Intézet és a Magyar Nemzeti Bank (melyek nem felsőoktatási intézmények). E mühelyeket így nem tudtuk figyelembe venni vizsgálatunk során.

Az MTMT mellett az Oktatási Hivatal legfrissebben elérhető, a 2017-es évre vonatkozó adatai alapján letöltöttük minden kar oktatói és hallgatói létszámát. ${ }^{10} \mathrm{~A}$ hallgatói létszámot a teljes munkaidővel egyenértékű (FTE) létszámra korrigáltuk, így a részidős képzések (esti, levelezős és távoktatás) diákjait 50 százalékos súllyal vettük figyelembe. ${ }^{11} \mathrm{Az}$ oktatói létszám nem állt rendelkezésre teljes és részmunkaidő szerinti bontásban, így ott ezt a korrekciót nem végeztük el.

A publikációs teljesítményt mérő mutatószámokat az elmúlt öt év alapján (2013-2017) állítjuk elö, a nemzetközi gyakorlathoz hasonlóan. Ezzel csökkentve annak a hatását, hogy valaki lassabban frissíti az MTMT-adatbázisát, kiküszöbölve az ingadozásokat, valamint számolva a publikációs és tudásteremtő folyamat hosszával.

Az elemzésben csak a gazdasági képzést nyújtó karokat vesszük figyelembe, mégpedig azokat, amelyek elnevezésében szerepel a következő szavak egyike: gazdaság, társadalom, kereskedelem, nemzetközi tanulmányok. ${ }^{12}$ A 25 kart tartalmazó teljes listát rövidítésekkel együtt a Függelék F1. táblázata tartalmazza.

Az elemzésekben összesen 21 különböző új indikátort vizsgálunk meg, valamint két indikátort, amelyet már eddig is használt a magyar rangsorolási gyakorlat: az egy hallgatóra jutó oktató és az egy hallgatóra jutó minősített oktató.

Az új mutatók számos módon ragadják meg a tudományos teljesítmény mérését, mindig annak valamelyik típusára helyezve a hangsúlyt. Az ÖsszEs ELÉRHETŐ PUBLIKÁcıó a tudományos teljesítmény mennyiségi jellegét ragadja meg, függetlenül azok minőségétől. Az összes MAGYAR PUBLIKÁCió és az ÖsszES KÜLFÖLDI PUBLIKÁCıÓ indikátorok elkülönítik a hazai és a nemzetközi kutatási teljesítményt. Az

\footnotetext{
${ }^{9}$ Valamint az összehasonlítás olyan szempontból is problémás lenne, hogy nem nyújtanak önálló alapképzést.

${ }^{10}$ https://www.oktatas.hu/felsooktatas/kozerdeku_adatok/felsooktatasi_adatok_kozzetetele/felso oktatasi_statisztikak.

${ }^{11}$ A QS és a THE rangsora is hasonló korrekciót végez, amelynek lényege, hogy figyelembe veszi a képzésformák és foglalkoztatásformák közti különbséget. Jelen tanulmányban ezt a következőképpen számítjuk: Teljes munkaidővel egyenértékű létszám = nappalis létszám $+($ esti + levelezős + távoktatásban részt vevők)/2.

${ }^{12}$ Kivétel ez alól a Pannon Egyetem Modern Filológiai és Társadalomtudományi Kar, hiszen elnevezésében szerepel a „társadalom” keresőszó, viszont a kar által nyújtott képzések egyike sem gazdasági jellegü, így nem tartjuk indokoltnak a szerepeltetését a listában.
} 
ÖSSZES KIVÁLÓ MAGYAR PUBLIKÁCIÓ és aZ ÖSSZES KIVÁLÓ KÜLFÖLDI publikáció már a minőségre koncentrál a mennyiség helyett, a két mérőszám külön kezeli a hazai és a nemzetközi kiváló publikációkat. Tehát az eddig bemutatott indikátorok vagy a mennyiségre, vagy a minőségre helyezték a hangsúlyt, így végül még további két indikátort is megvizsgálunk, ahol ennek a két tulajdonságnak egy adott súlyozását használjuk. A hatvánYozotT súlyozás kiemelten nagy súlyt ad a kiváló és külföldi publikációknak, míg a LINEÁRIs súlyozÁs kisebb, de még mindig jelentős súlyt ad a kiváló és külföldi publikációknak.

Ez a hét új mutató képezi az alapját a tudományos teljesítmények mérésének (2. táblázat). Az összehasonlíthatóság miatt fontos figyelembe venni, hogy egy adott kar tudományos teljesítményét hány oktató éri el. Ezért képzünk újabb hét indikátort, ahol az eddigi mérőszámok értékét elosztjuk a tanárok számával. Végül talán a legfontosabb kérdés, hogy a diákok számához viszonyítva mekkora a tudományos teljesítmény. Ehhez az eddigi hét új indikátor értékét elosztjuk a diákok számával. A tudományos teljesítményt a diákok számához mérő indikátorok jól ragadják meg, hogy átlagosan mennyi kutatói munkával tud találkozni a diák a felsőoktatásban, és mekkora esélye van, hogy a legújabb tudományos eredményekkel ismerkedjen meg.

\section{2. táblázat}

A tanulmány tudományos teljesítményt mérő mutatószámai

A mérőszám neve

A mérőszám tartalma

Egy hallgatóra jutó oktató A tanárok száma osztva a hallgatói létszámmal (FTE) a karon.

Egy hallgatóra jutó

minősített oktató

Az adott karon föiskolai vagy egyetemi tanár, docens vagy adjunktus munkakörben dolgozók összlétszáma osztva a hallgatók (FTE) létszámával.

Összes publikáció $\quad$ Az adott időszak alatt összesen publikált tudományos eredmény.

Összes magyar publikáció Az adott időszak alatt magyar nyelven publikált összes tudományos eredmény.

Összes külföldi publikáció Az adott időszak alatt angol nyelven publikált összes tudományos eredmény.

Összes kiváló magyar publikáció

Az adott időszak alatt magyar nyelven $A$ besorolású folyóiratban publikált összes tudományos eredmény

Összes kiváló külföldi publikáció Az adott időszak alatt angol nyelven $A$ besorolású folyóiratban publikált összes tudományos eredmény

Hatványozottan súlyozott Az adott időszak alatt publikált tudományos eredmények a összes publikáció következő súllyal: nemzetközi: $A$ : 128 pont, $B$ : 64 pont, $C$ : 32 pont, $D$ : 16 pont; magyar: $A: 8$ pont, $B: 4$ pont, $C: 2$ pont, $D: 1$ pont.

Lineárisan súlyozott összes publikáció
Az adott időszak alatt publikált tudományos eredmények a következő súllyal: nemzetközi: $A: 8$ pont, $B: 7$ pont, $C: 6$ pont, $D: 5$ pont; magyar: $A$ : 4 pont, $B: 3$ pont, $C: 2$ pont, $D: 1$ pont.

\footnotetext{
* A súlyrendszer módosítása, pontosítása további kutatások témáját képezheti, jelen példa csak egy lehetséges illusztrációt vázol fel.
} 
Ezeket a mérőszámokat szintén képezzük oktatóarányosan és hallgatóarányosan. Az első esetben a kapott mérőszámot az oktatók számával osztjuk el, míg a második esetben a hallgatók számával.

\section{A mutatószámok értékelése a magyar gazdasági felsőoktatási képzésekre}

Következőkben bemutatjuk a rangsorokat az ismertetett mérőszámok alapján, hogy áttekinthető legyen a számítások módja, majd két fontos kérdést vizsgálunk meg. Az első, hogy mennyire kapjuk ugyanazt az eredményt különböző indikátorok használata esetén. Tehát mennyire érzékeny ez az új szempont arra, hogy melyik mérőszámot választjuk. A második fontos kérdés, hogy ez ad-e új információt a már ismert tanár/ diák arányhoz képest. Ha ez az új szempont nagymértékben korrelál vagy legalábbis ugyanarra a következtetésre jut, mint a tanár/diák arány szempont, akkor felesleges beépíteni a magyar rangsorokba.

Először a hallgatóarányos publikációs mutatókat elemezzük, mivel a jövőbeli hallgatók számára ez ad a legtöbb információt arról, hogy várhatóan mekkora tudásmennyiséget kap egy diák ezen a téren. Ezt követően az oktatóarányos publikációs mérőszámokat vizsgáljuk, amelyek megmutatják az egy tanárra jutó átlagos tudományos teljesítményt, ${ }^{13}$ majd a méretfüggő (tehát nem arányosított) indikátorokat, amelyek az adott kar egészének teljesítményét fejezik ki. A publikációs mutatók elemzése után a tanár/diák arány jellegü mérőszámok következnek, végül pedig összevetjük a kapott eredményeket: korrelációs számításokat végezve számszerűsítjük az összefüggést - vagy éppen annak hiányát - a fent említett indikátorok között.

\section{Hallgatóarányos publikációs mutatók}

A 3. táblázatban a különböző publikációs mutatók hallgatóarányos értékei alapján elért helyezések láthatók, a publikációk lineáris súlyozásának egy diákra jutó értéke szerinti sorrendben. ${ }^{14} \mathrm{~A}$ továbbiakban az átláthatóság érdekében csak a lista elejét mutatjuk be, azon karokat, amelyek legalább az egyik mutató alapján a legjobb ötbe tartoznak. A rangsorképzés alapját adó eredeti, teljes, nyers mutatókat tartalmazó adatokat a Függelék F2. táblázata tartalmazza.

\footnotetext{
${ }^{13}$ Feltételezhető, hogy a publikációs teljesítmény karon belül aszimmetrikus eloszlású az oktatók között. Vannak kiugró teljesítményű kutatók, így az átlag mint középérték interpretációját óvatosan érdemes kezelni.

${ }^{14}$ Azonos sorszámú érték esetén a sorszámok átlaga jelenik meg, így tizedestörtek is előfordulhatnak a rangsorban.
} 
3. táblázat

Rangsorok a hallgatóarányos publikációs mutatók alapján

\begin{tabular}{lccccccc}
\hline & Összes & Magyar & Külföldi & Magyar A & Külföldi A & Exponenciális & Lineáris \\
\hline BCE KK & 1. & 1. & 1. & 1. & 1. & 1. & 1. \\
PTE KTK & 2. & 3. & 2. & 2. & 2. & 2. & 2. \\
BCE TK & 3. & 4. & 5. & 4. & 4. & 3. & 3. \\
BCE GK & 5. & 6. & 4. & 5 & 6. & 4. & 4 \\
SZTE GTK & 6. & 5. & 6. & 3. & 11. & 8. & 5. \\
PE GTK & 7. & 9. & 3. & 8. & 8. & 6. & 6. \\
ELTE TATK & 8. & 8. & 7. & 6. & 3. & 5. & 7. \\
KE GTK & 4. & 2. & 14. & 11. & $19,5$. & 13. & 8. \\
SOE LKK & 16. & 18. & 9. & $22,5$. & 5. & 7. & 13. \\
\hline
\end{tabular}

Forrás: Oktatási Hivatal, MTMT alapján saját számítás.

A vizsgált mutatók alapján általában a BCE KK, a PTE KTK és a BCE TK szerepelnek a lista élén, rajtuk kívül a KE GTK erősnek mutatkozik a magyar nyelvű publikációk terén, a SZE GTK a kiváló magyar nyelvü, a PE GTK a külföldi, az ELTE TATK pedig a kiváló külföldi publikációkat figyelembe véve ér el dobogós helyezést. A top ötben a BCE GK és a SOE LKK kap még helyet.

\section{Oktatóarányos publikációs mutatók}

A publikációs mérőszámok egy oktatóra jutó értéke is az előbbihez nagyon hasonló sorrendet eredményez (4. táblázat). Az első két helyet a BCE KK és a PTE KTK foglalja el itt is, a lista első hét helyezettje megegyezik. A KE GTK és a SOE LKK kikerül a top5-ből, viszont az ő esetükben sem tapasztalható jelentős mozgás, csupán néhány helyet változnak a különböző mutatók.

\section{4. táblázat}

Rangsorok az oktatóarányos publikációs mutatók alapján

\begin{tabular}{lccccccc}
\hline & Összes & Magyar & Külföldi & Magyar A & Külföldi A Exponenciális & Lineáris \\
\hline BCE KK & 1. & 2. & 1. & 1. & 1. & 1. & 1. \\
PTE KTK & 2. & 1. & 3. & 2. & 2. & 2. & 2. \\
BCE GK & 3. & 3. & 2. & 4. & 3. & 3. & 3. \\
SZTE GTK & 4. & 4. & 5. & 3. & 11. & 7. & 4. \\
BCE TK & 5. & 5. & 6. & 5. & 5. & 4. & 5. \\
PE GTK & 6. & 6. & 4. & 7. & 6. & 6. & 6. \\
ELTE TATK & 7. & 7. & 7. & 6. & 4. & 5. & 7. \\
\hline
\end{tabular}

Forrás: Oktatási Hivatal, MTMT alapján saját számítás. 
A rangsoron kívül a nyers mutatókat is megnézve az látható, hogy erősen tagolt a mezőny (5. táblázat). Az összes publikáció oktatóarányos számában az első helyen áll a BCE KK 2,4-del, a PTE KTK követi 2,1-del és a BCE GK 1,9-del. Egy körüli értékkel rendelkeznek még, sorban: SZTE GTK, BCE TK, PE GTK és ELTE TATK, az átlag pedig 0,7.

A következőkben az oktatóarányos mutatók néhány érdekességére hívjuk fel a figyelmet. Az egy tanárra jutó tudományos teljesítmény nyers adatait vizsgálva láthatjuk, hogy a legmagasabb az összes publikáció száma $(0,71)$, amelynek nagy része magyar nyelvü $(0,58)$, valamint csupán töredéke $(0,13)$ az $A$ besorolású külföldi (5. táblázat). Az átlaggal ellentétes irányban változik a relatív szórás: a legnagyobb relatív szórással ez utóbbi kategóriában, tehát a kiváló külföldi publikációk esetében találkozunk. Itt a BCE KK és a PTE KTK kiemelkedik a karok közül, rendre 0,2 és 0,15-os értékkel, míg a harmadik helyezett BCE GK ennél jóval alacsonyabb értéket mutat (0,09), az átlag pedig csupán 0,03. A 25 vizsgált karból 12 egyáltalán nem rendelkezik külföldi $A$ kategóriás publikációval. A második legnagyobb relatív szórás a kiváló magyar publikációk számában van, a legkisebb pedig az összes magyar publikációéban. A relatív szórások elemzése megmutatja, hogy minél jobban haladunk a magyar nyelvütől a külföldi felé, valamint az összes publikáció figyelembevétele helyett nagyobb hangsúlyt fektetünk a különböző besorolásokra (a mennyiség helyett a minőséget helyezzük elötérbe), annál jelentősebb a szóródás a karok között, tehát annál tagoltabb lesz a mezőny.

\section{5. táblázat}

A nyers, oktatóarányos publikációs mutatók átlaga és relatív szórása

\begin{tabular}{lccccccc}
\hline & Összes & Magyar & Külföldi & Magyar $A$ & Külföldi $A$ & Exponenciális & Lineáris \\
\hline Átlag & 0,71 & 0,58 & 0,13 & 0,08 & 0,03 & 9,32 & 2,18 \\
Relatív szórás & 0,94 & 0,87 & 1,41 & 1,65 & 1,75 & 1,42 & 1,12 \\
\hline
\end{tabular}

Forrás: Oktatási Hivatal, MTMT alapján saját számítás.

\section{Méretfüggö publikációs mutatók}

Az eddigi indikátorok mind figyelembe vették az intézmény méretét, vagy az oktatói, vagy a hallgatói létszámon keresztül. A 6. táblázat mutatja azokat az eredményeket, amelyeket úgy kaptunk, hogy nem korrigáltunk az intézmény méretével. Az első öt helyen szereplő karok egy kivétellel megegyeznek: a PE GTK-t a BME GTK váltja, mivel a PE GTK - aránylag kis méretéből adódóan néhány helyet hátrébb csúszik, a BME GTK pedig javít helyezésein. A kiváló magyar és külföldi publikációk szerint a BCE KK megtartja az első helyét, viszont a többi mérőszám esetében a $\mathrm{BCE}$ GK veszi át a vezetést, amely kiemelkedően jól teljesít ebben a kategóriában - ami részben a BCE KK-hoz képest kétszer nagyobb oktatói gárdájának köszönhetö. 
6. táblázat

Rangsorok a méretfüggő publikációs mutatók alapján

\begin{tabular}{lccccccc}
\hline & Összes & Magyar & Külföldi & Magyar A & Külföldi A & Exponenciális & Lineáris \\
\hline BCE GK & 1. & 1. & 1. & 2. & 2. & 1. & 1. \\
BCE KK & 2. & 2. & 2. & 1. & 1. & 2. & 2. \\
BCE TK & 3. & 3. & 4. & $4,5$. & 4. & 4. & 3. \\
PTE KTK & 4. & 4. & 5. & 3. & 3. & 3. & 4. \\
BME GTK & 5. & 8. & 3. & 6. & 6. & 5. & 5. \\
SZTE GTK & 6. & 5. & 7. & $4,5$. & $11,5$. & 9. & 6. \\
ELTE TATK & 9. & 9. & 9. & 7. & 5. & 6. & 9. \\
\hline
\end{tabular}

Forrás: Oktatási Hivatal, MTMT alapján saját számítás.

Az egy före jutó értékre való korrekció elősegíti a méret okozta torzítás csökkentését, így az aránylag kisebb karoknak kedvez, valamelyest átrendezve a sorrend első negyedét. Érdemes megnézni például a publikációk lineáris súlyozása alapján kialakult sorrend, valamint az ennek egy tanárra jutó változata közti különbséget: a mérethatással való korrigálás eredményeképp a PE GTK, a PTE KTK és a SZTE GTK két-két helyet javít, a BCE KK pedig az első helyre jön fel, míg a BME GTK négy helyezést ront, valamint a BCE GK és a BCE TK két-két hellyel hátrébb kerül.

Az összes publikációk száma hasonló eredményt mutat. A nyers mutatószámok a karok közti különbségek nagyságáról is információval szolgálnak. Itt a mezőny eleje szintén elszakad a többiektől, hiszen a BCE GTK vezeti a listát 463 publikációval, ezt követi a BCE KK 275 és a BCE TK 204-es értékekkel, majd a PTE KTK következik 164-gyel, míg az átlagos publikációs szám 84.

A nemzetközi versenyképesség szempontjából lényeges tényező lehet az $A$ besorolású külföldi publikációk száma. A vizsgált karok közül csupán hatról mondható el, hogy az ötéves periódus alatt évente átlagosan legalább egy ilyen publikációval rendelkezik. Idetartozik a BCE három kara, a PTE KTK, az ELTE TATK és a BME GTK. A karok majdnem felénél, 12 helyen pedig egyáltalán nincsen ilyen publikáció.

A lista vége szintén elszakad a középmezőnytől, öt kar is 10 alatti tudományos müvet publikált az elmúlt ötéves időszakban, közülük viszont hárman is a tanár/diák arányt tekintve az első harmadban helyezkednek el. Ugyanezen mutató egy oktatóra jutó értékeit nézve hasonlóan rendeződik át a mezőny, mint az előbbi példában (lineáris súlyozás): az első helyre jön föl a BCE KK, ezt követi a PTE KTK két helyet javítva, majd a BCE GK és a BCE TK kettő, valamint egy helyezést hátrébb csúszva.

\section{Tanár/diák arány jellegü mutatók}

Az egy diákra jutó minősített oktatói létszámot tekintve a GFF TSZK, a SZIE AGK és a KE GTK képzései foglalják el az első három helyet (7. táblázat). A már részletezett publikációalapú rangsorok első öt helyezettjei közül csupán a BCE KK található 
meg itt is, ami szemlélteti, hogy ebben az esetben a korábbiaktól jóval eltérő sorrendet tapasztalhatunk. A nyers mutatók relatív szórása itt kisebb, mint a publikációs mérőszámoknál: az egy diákra jutó tanárok számának 0,7 , a minősített oktatók hallgatóarányos létszámának 0,6, tehát itt kevésbé szóródik a mezőny.

\section{7. táblázat}

Rangsorok a tanár/diák arány jellegü mutatók alapján

\begin{tabular}{lcc}
\hline & Tanár/diák & Minősített tanár/diák \\
\hline GFF TSZK & 1. & 1. \\
SZIE AGK & 2. & 2. \\
KE GTK & 4. & 3. \\
BCE KK & 6. & 4. \\
NKE NET & 8. & 5. \\
SOE LKK & 5. & 6. \\
BGE GKZ & 3. & 8. \\
\hline
\end{tabular}

Forrás: Oktatási Hivatal, MTMT alapján saját számítás.

Érdemes lenne az oktatók számához a teljes és részmunkaidőben foglalkoztatottakat is megkülönböztetni, viszont - a következőkben bemutatott robusztus eredmények alapján - a sorrendben nem várható jelentős változás.

Ezek az eredmények mind azt sugallják, hogy a tudományos publikációk alapján képzett mutatók érdemben különböző információt tartalmaznak, mint a tanár/ diák mutatók.

\section{A különbözö típusú mutatók összefüggései}

A fent bemutatott indikátorokról elmondható, hogy a helyezések nagyjából stabilnak mutatkoznak különbözö publikációs méröszámokat használva, valamint ezek jelentősen eltérnek a tanár/diák arány alapján kialakult sorrendtől.

A publikációs mutatók által kialakított sorrendek között erős összefüggés figyelhető meg, hiszen a rangkorrelációk legtöbbje 0,8-0,9 körüli érték. A 8. táblázat a hallgatóarányos indikátorok közötti kapcsolatot mutatja, ezen méröszámcsoportnál az átlagos korreláció 0,81 . A leggyengébb összefüggés a külföldi $A$ és az összes magyar, illetve a magyar $A$ kategóriájú publikációk között van ( $r=0,55$ és 0,54$)$, tehát az idegen nyelven való publikálás a magyartól valamelyest eltérő sorrendet eredményez. Az összes, a magyar és a lineáris súlyozású mérőszámok által kialakult sorrendek között erős pozitív (0,9-es) értéket meghaladó korreláció áll fönn, ami azt jelenti, hogy ezen három mutató szorosan összekapcsolódik olyan szempontból, hogy hasonlóképpen méri a tudományos teljesítményt az elemzésben szereplő karok közt. Az exponenciális súlyozású és a külföldi A között szintén erős a kapcsolat, ami nem meglepő, hiszen az exponenciális súlyozásúnál a kiváló külföldi publikációkat vettük számításba messze a legnagyobb súllyal. 
8. táblázat

Hallgatóarányos mutatók rangkorrelációs mátrixa

\begin{tabular}{|c|c|c|c|c|c|c|c|c|c|}
\hline & $\begin{array}{c}\text { Tanár/ } \\
\text { diák }\end{array}$ & $\begin{array}{l}\text { Minősített } \\
\text { tanár/diák }\end{array}$ & Összes & Magyar & Külföldi & $\begin{array}{c}\text { Magyar } \\
A\end{array}$ & $\begin{array}{c}\text { Külföldi } \\
A\end{array}$ & $\begin{array}{c}\text { Expo- } \\
\text { nenciális }\end{array}$ & Lineáris \\
\hline Tanár/diák & 1 & & & & & & & & \\
\hline $\begin{array}{l}\text { Minősített } \\
\text { tanár/diák }\end{array}$ & 0,76 & 1 & & & & & & & \\
\hline Összes & $-0,29$ & 0,17 & 1 & & & & & & \\
\hline Magyar & $-0,21$ & 0,25 & 0,98 & 1 & & & & & \\
\hline Külföldi & $-0,49$ & $-0,15$ & 0,80 & 0,71 & 1 & & & & \\
\hline Magyar $A$ & $-0,42$ & $-0,06$ & 0,78 & 0,76 & 0,75 & 1 & & & \\
\hline Külföldi $A$ & $-0,30$ & $-0,03$ & 0,66 & 0,55 & 0,84 & 0,54 & 1 & & \\
\hline Exponenciális & $-0,38$ & 0,00 & 0,87 & 0,78 & 0,94 & 0,72 & 0,92 & 1 & \\
\hline Lineáris & $-0,36$ & 0,06 & 0,97 & 0,92 & 0,90 & 0,82 & 0,77 & 0,94 & 1 \\
\hline
\end{tabular}

Forrás: Oktatási Hivatal, MTMT alapján saját számítás.

A publikációs mérőszámok közötti korrelációk nemcsak a rangsoroláskor, hanem a nyers adatok esetében is szoros összefüggést mutatnak: a különböző méretfüggő publikációs mutatók közti rangkorreláció átlagosan $r=0,9$, a korreláció pedig átlagosan $r=0,93$. Ráadásul nemcsak az átlagos értékek magasak, hanem a rangkorreláció minden esetben legalább 0,72, míg a korreláció mindig legalább 0,8. A tudományos publikációs teljesítmény oktatóarányos értékei erősen korrelálnak a megfelelö eredeti adatokkal, csakúgy, mint a hallgatóarányos mérőszámok: rendre átlagosan $r=0,88$, illetve 0,73 -os értékkel. Az 1-től való eltérés a már említett mérethatással való korrekcióból adódik.

A 8. táblázatban látható, hogy a minősített tanár/diák arány alapján kialakult sorrend élesen elkülönül a többi mutató eredményeitől, hiszen a Spearman-féle rangkorrelációs együttható nem szignifikáns az egy diákra jutó minősített oktató és akármelyik publikációs mutató között 5 százalékos szignifikanciaszinten. ${ }^{15}$ Kivételt képez a tanár/diák arány, amellyel értelemszerüen erős rangkorrelációt mutat $(r=0,76)$. A tanár/diák arány a legtöbb publikációs mutatóval szintén nem korrelál ${ }^{16}$ (vagy gyenge negatív irányú szignifikáns kapcsolatot mutat, mint a külföldi, illetve a magyar $A$ besorolásúak esetében), ami arra enged következtetni, hogy a különböző módokon mért publikációk száma nem függ össze sem a tanárok, sem a minősített oktatók számával, hanem a minőségi oktatás egy más szempontját ragadja meg.

Tehát nem áll fenn kapcsolat a UnivPress rangsorban jelenleg használt minősített tanár/diák arány és a különböző publikációs mérőszámok között, ami azt jelenti, hogy az általunk képzett publikációs mutatók új információval szolgálnak a képzés minőségéről, így érdemes őket beépíteni a felsőoktatási rangsorolási gyakorlatba.

\footnotetext{
${ }^{15}$ A határérték $\pm 0,396$.

${ }^{16}$ Rangsor helyett a nyers mutatókkal számolva kivétel nélkül nem szignifikáns értékeket kapunk.
} 


\section{Következtetések}

A publikációk száma fontos szempont a nemzetközi felsőoktatási rangsoroknál, viszont a magyar gyakorlat nem használ bibliográfiai mutatókat. Tanulmányunk a magyar felsőoktatás gazdasági képzést nyújtó karainak MTMT-n alapuló egyedi adatait elemezve bemutat több lehetséges példát arra, hogy miként lehetne a tudományos publikációk alapján egy fontos új szempontot beépíteni a hazai egyetemi rangsorokba. Megmutattuk, hogy a különböző mérőszámok (például összes publikáció száma, külön magyar és angol nyelvü, valamint $A, B, C$ besorolású különböző súlyokkal, valamint ezek egy före jutó száma) nagyon hasonló képet mutatnak. Ez azt jelenti, hogy a tudományos publikáción alapuló új szempont robusztus eredményt ad, beépíthető a hazai felsőoktatási rangsorolási gyakorlatba.

Erre egy lehetséges megoldás például a bemutatott lineáris súlyozású, hallgatóarányos mutató, mivel ez a publikációk minőségét is figyelembe veszi, valamint korrigál a mérethatással is. A súlyrendszer módosítása, pontosítása további kutatások témája lehet, jelen példa csak egy illusztrációt vázol fel. ${ }^{17}$

A tudományos teljesítményt a UnivPress rangsorában az oktatók minősítései (habilitáció, MTA-doktori cím), valamint a minősített oktatóra jutó nappalis hallgatók száma próbálja megjeleníteni, elemzésünk viszont rámutatott, hogy ez utóbbi nincs összhangban a publikációs eredményekkel. A tanár/diák arány jellegű mutatók nem korrelálnak szignifikánsan az általunk képzett publikációs mutatókkal, tehát ez utóbbiak új információt tartalmaznak. A tanulmány eredményei remélhetöleg elősegítik a publikációs teljesítmény rangsorokba való beépülésének folyamatát, amely a kutatási eredmények mérésével hangsúlyt helyez az egyetemeken folyó kutatói munkára, ösztönzi azt, serkentve az innovációt, valamint elősegíti a felsőoktatás színvonalának növelését.

\section{Hivatkozások}

ARWU [2018]: Academic Ranking of World Universities. Methodology. Shanghai Ranking Consultancy, Sanghaj, március 16. http://www.shanghairanking.com/ARWU-FIELDMethodology-2016.html.

BennetT, D. C. [2001]: Assessing Quality in Higher Education. Liberal Education, Vol. 87. No. 2. https://www.aacu.org/publications-research/periodicals/assessing-quality-higher-education.

BrooKs, R. [2005]: Measuring University Quality. The Review of Higher Education, Vol. 29. No. 1. 1-21. o. https://doi.org/10.1353/rhe.2005.0061.

CAKIR, M.-ACARTÜrk, C.-Alaşehir, O.-ÇıLINGir, C. [2015]: A comparative analysis of global and national university ranking systems. Scientometrics, Vol. 103. No. 3. 813-848. o. https://doi.org/10.1007/s11192-015-1586-6.

Chatzimichael, K.-Kalaitzidakis, P.-Tzouvelekas, V. [2017]: Measuring the publishing productivity of economics departments in Europe. Scientometrics, Vol. 113. No. 2. 889-908. o. https://doi.org/10.1007/s11192-017-2509-5.

${ }^{17}$ A tényleges rangsorok természetesen mind a vizsgált időszak, mind a bevont mutatók köre, mind pedig ezek súlyozása függvényében módosulhatnak. Itt emelnénk ismételten ki, hogy az általunk választott vizsgálati módszertan következtében a megfigyelési egységeink egyetemi karok voltak, így az illusztrációként szereplő rangsorokban számos elismert hazai tudományos mühely nem szerepel. 
Claassen, C. [2015]: Measuring university quality. Scientometrics, Vol. 104. No. 3. 793-807. o. https://doi.org/10.1007/s11192-015-1584-8.

Csaba LÁszló-Szentes Tamás-Zalai Ernő [2014]: Tudományos-e a tudománymérés? Megjegyzések a tudománymetria, az impaktfaktor és MTMT használatához. Magyar Tudomány, 175. évf. 4. sz. 442-466. o.

Csató LÁszló [2013]: Rangsorolás páros összehasonlításokkal. Kiegészítések a felvételizői preferencia-sorrendek módszertanához. Közgazdasági Szemle, 60. évf. 12. sz. 1333-1353. o.

CsATó LÁszLó [2016]: Felsőoktatási rangsorok jelentkezői preferenciák alapján. Közgazdasági Szemle, 63. évf. 1. sz. 27-61. o. https://doi.org/10.18414/KSZ.2016.1.27.

FÁBRI GYÖRGY [2016]: Az egyetem értéke. Felsőoktatási rangsorok és az egyetemi teljesítmény. ELTE Eötvös Kiadó, Budapest.

HazelkoRn, E. [2007]: The impact of league tables and ranking systems on higher education decision making. Higher Education Management and Policy, Vol. 19. No. 2. 1-24. o. https://doi.org/10.1787/hemp-v19-art12-en.

Johnes, G. [1987]: Research Performance Indications in the University Sector. Higher Education Quarterly, Vol. 42. No. 1. 54-71. o. https://doi.org/10.1111/j.1468-2273.1987.tb02114.x.

Johnes, J. [2018]: University rankings: What do they really show? Scientometrics, Vol. 115. No. 1. 585-606. o. https://doi.org/10.1007/s11192-018-2666-1.

LEIDEN RANKING [2018]: Indicators. CWTS Leiden Ranking, 2018. http://www.leidenranking. com/information/indicators.

MargInson, S. [2014]: University rankings and social science. European Journal of Education, Vol. 49. No. 1. 45-59. o. https://doi.org/10.1111/ejed.12061.

Moed, H. F. [2017]: A critical comparative analysis of five world university rankings. Scientometrics, Vol. 110. No. 2. 967-990. o. https://doi.org/10.1007/s11192-016-2212-y.

Morse, R.-Krivian, A.-Martin, E. [2019]: How U.S. News Calculated the Best Global Universities Rankings. Find out how U.S. News determined the world's top universities overall and by region and country. US NEWS, október 29. https://www.usnews.com/education/ best-global-universities/articles/methodology.

PollitT, C. [1990]: Measuring University Performance: Never Mind the Quality, Never Mind the Width? Higher Education Quarterly, Vol. 44. No. 1. 60-81. o. https://doi.org/10.1111/ j.1468-2273.1990.tb01525.x.

QS [2018]: Methodology, március 16. https://www.topuniversities.com/qs-world-universityrankings/methodology.

SAFón, V. [2013]: What do global university rankings really measure? The search for the $\mathrm{X}$ factor and the X entity. Scientometrics, Vol. 97. No. 2. 223-244. o. https://doi.org/10.1007/ s11192-013-0986-8.

ScImago [2018]: SIR Methodology. http://www.scimagoir.com/methodology.php.

Tachibana, C. [2017]: New tools for measuring academic performance. Science, február 10. https://doi.org/10.1126/science.opms.r1700173.

THE [2018]: World University Rankings 2016-2017 methodology. THE World Universities Insights Limited, London, https://www.timeshighereducation.com/world-universityrankings/methodology-world-university-rankings-2016-2017.

Telcs András-Kosztány Zsolt Tibor-Török Ádám [2013]: Hallgatói preferenciasorrendek készítése az egyetemi jelentkezések alapján. Közgazdasági Szemle, 60. évf. 3. sz. 290-317. o.

Toutkoushian, R. K.-Porter, S. R.-Danielson, C.-Hollis, P. R. [2003]: Using Publications Counts to Measure an Institution's Research Productivity. Research in Higher Education, Vol. 44. No. 2. 121-148. o. https://doi.org/10.1023/a:1022070227966. 
TöRÖк ÁDÁm [2008]: A mezőny és tükörképei - Megjegyzések a magyar felsőoktatási rangsorok hasznáról és korlátairól. Közgazdasági Szemle, 55. évf. 10. sz. 874-890. o.

U-Multirank [2018]: Catalogue of Indicators. https://www.umultirank.org/\#!/measures? trackType $=$ about $\&$ sightMode $=$ undefined $\&$ section $=$ undefined $\&$ name $=$ null .

Webometrics [2018]: Methodology. http://www.webometrics.info/en/Methodology.

Witte, K.-Hudrlikova, L. [2013]: What about excellence in teaching? A benevolent ranking of universities. Scientometrics, Vol. 96. No. 1. 337-364. o. https://doi.org/10.1007/s11192013-0971-2.

\section{Függelék}

F1. táblázat

Az elemzésben szereplő karok

\begin{tabular}{|c|c|}
\hline Rövidítés & Teljes elnevezés \\
\hline BCE GK & Budapesti Corvinus Egyetem Gazdálkodástudományi Kar \\
\hline BCE KK & Budapesti Corvinus Egyetem Közgazdaságtudományi Kar \\
\hline BCE TK & Budapesti Corvinus Egyetem Társadalomtudományi Kar \\
\hline BGE GKZ & Budapesti Gazdasági Egyetem Gazdálkodási Kar, Zalaegerszeg \\
\hline BGE KKK & Budapesti Gazdasági Egyetem Külkereskedelmi Kar \\
\hline BGE KVIK & $\begin{array}{l}\text { Budapesti Gazdasági Egyetem Kereskedelmi, Vendéglátóipari } \\
\text { és Idegenforgalmi Kar }\end{array}$ \\
\hline BGE PSZK & Budapesti Gazdasági Egyetem Pénzügyi és Számviteli Kar \\
\hline BME GTK & $\begin{array}{l}\text { Budapesti Műszaki és Gazdaságtudományi Egyetem Gazdaság- } \\
\text { és Társadalomtudományi Kar }\end{array}$ \\
\hline DE GTK & Debreceni Egyetem Gazdaságtudományi Kar \\
\hline EKE GTK & Eszterházy Károly Egyetem Gazdaság- és Társadalomtudományi Kar \\
\hline ELTE TATK & Eötvös Loránd Tudományegyetem Társadalomtudományi Kar \\
\hline GFF TSZK & Gál Ferenc Főiskola Társadalomtudományi és Szociális Képzési Kar \\
\hline KE GTK & Kaposvári Egyetem Gazdaságtudományi Kar \\
\hline ME GTK & Miskolci Egyetem Gazdaságtudományi Kar \\
\hline MET HFTGK & Budapesti Metropolitan Egyetem Heller Farkas Turisztikai és Gazdasági Kar \\
\hline NJE GK & Neumann János Egyetem Gazdálkodási Kar \\
\hline NKE NET & Nemzeti Közszolgálati Egyetem Nemzetközi és Európai Tanulmányok Kar \\
\hline ÓE KKGK & Óbudai Egyetem Keleti Károly Gazdasági Kar \\
\hline PE GTK & Pannon Egyetem Gazdaságtudományi Kar \\
\hline PTE KTK & Pécsi Tudományegyetem Közgazdaságtudományi Kar \\
\hline SOE LKK & Soproni Egyetem Lámfalussy Sándor Közgazdaságtudományi Kar \\
\hline SZE KGYK & Széchenyi István Egyetem Kautz Gyula Gazdaságtudományi Kar \\
\hline SZIE AGK & Szent István Egyetem Agrár- és Gazdaságtudományi Kar \\
\hline SZIE GTK & Szent István Egyetem Gazdaság- és Társadalomtudományi Kar \\
\hline SZTE GTK & Szegedi Tudományegyetem Gazdaságtudományi Kar \\
\hline
\end{tabular}




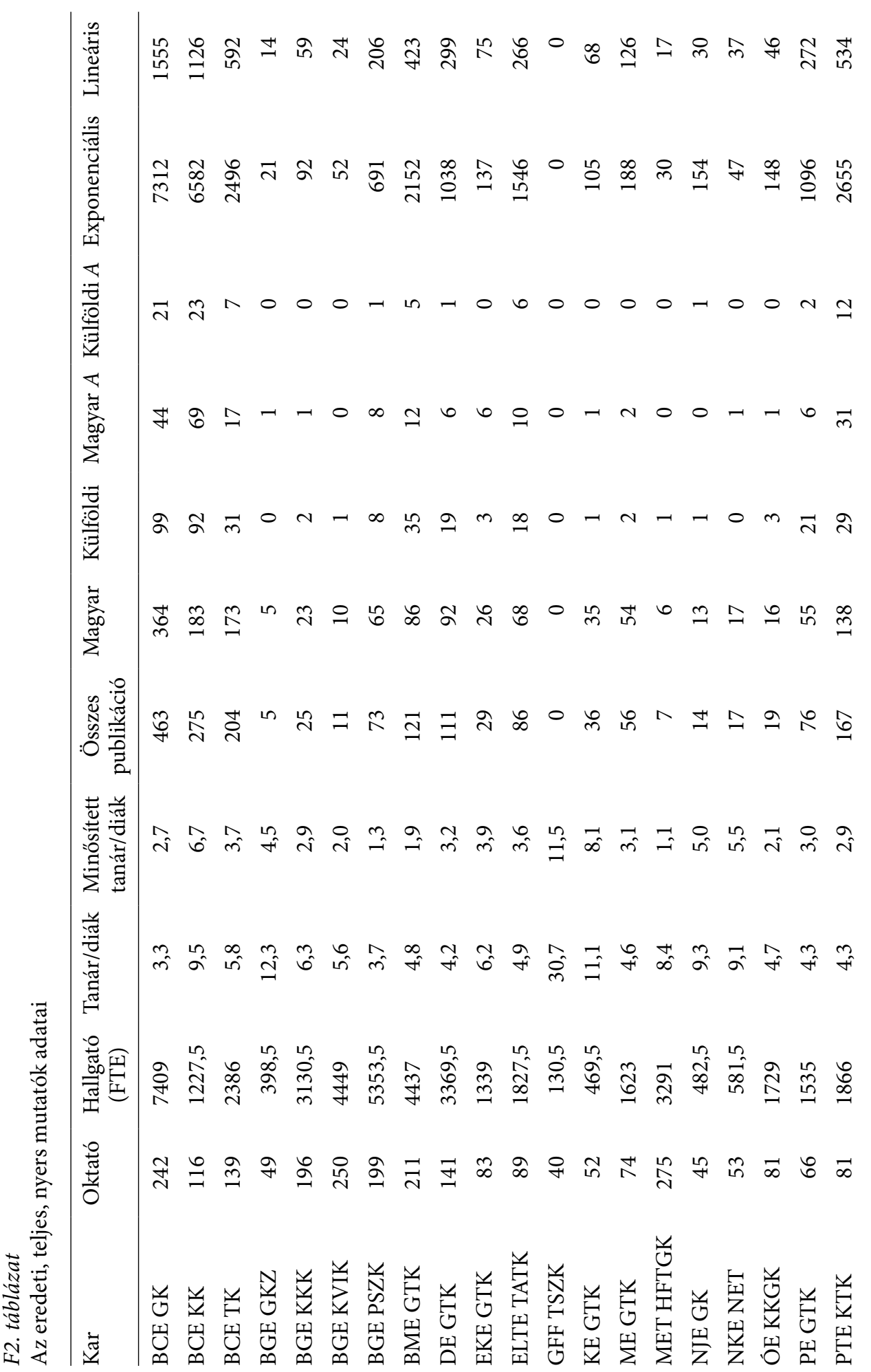




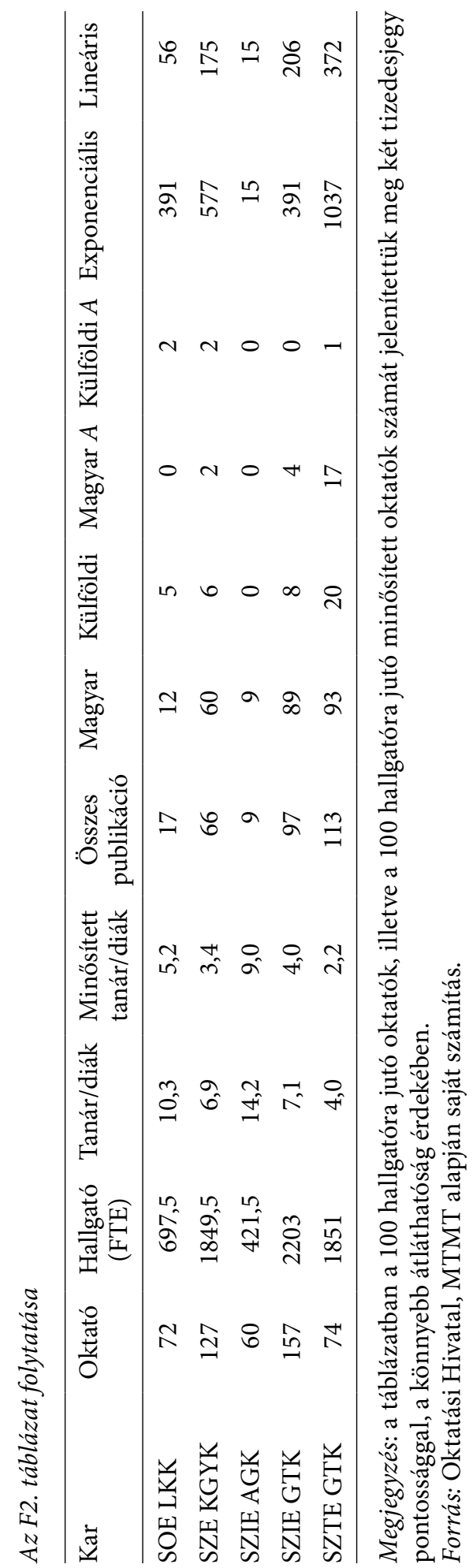

